\title{
A Phraseological Approach to the Shift between Subjunctives from Were to Was: The Case of As It Were and As It Was
}

\author{
Ai Inoue ${ }^{1}$ \\ ${ }^{1}$ Associate Professor, Department of Foreign Languages, National Defense Academy of Japan, Japan \\ Correspondence: Ai Inoue, Department of Foreign Languages, National Defense Academy of Japan, 1-10-20 \\ Hashirimizu, Yokosuka City, Kanagawa Prefecture, 239-8686, Japan. E-mail: aiinoue@nda.ac.jp
}

Received: May 30, 2015 Accepted: June 16, 2015 Online Published: September 29, 2015

doi:10.5539/ijel.v5n5p14 URL: http://dx.doi.org/10.5539/ijel.v5n5p14

\begin{abstract}
The subjunctive were tends to be interchangeably used with the subjunctive was (e.g., If I were/was rich, I would buy you anything you wanted (Quirk et al., 1985)). According to Webster's Dictionary of English Usage (1989), the subjunctive was started to be used instead of the subjunctive were at the end of the $16^{\text {th }}$ century and was frequently used by the end of the $17^{\text {th }}$ century. The dictionary also mentions that the subjunctive was was used for emphasis; however, tokens of the subjunctive was appeared in less formal language styles. It has been widely acknowledged that the subjunctives were and was are not interchangeable in phraseological units such as if I were you and as it were. Examining instances obtained from corpora, we see the interesting phenomenon of the subjunctive were being replaced by the subjunctive was in the phraseological unit if I were you. From these cases, it can be assumed that the subjunctive were is interchangeable with the subjunctive was in if I were/was you regardless of the registers in which it is used. This phenomenon can be accounted for by the merger of was and were. This study aims to descriptively show how as it were changed into as it was from a phraseological perspective. Furthermore, an analysis of corpora data allows us to explain in detail the actual behaviors of as it was and its relationship with as it were.
\end{abstract}

Keywords: phraseology, subjunctive were, subjunctive was, as it were, as it was, merging

\section{Introduction}

General belief has held that the subjunctive was is not interchangeable with the subjunctive were in the phraseological units (PUs) (Note 1) if I were you and as it were. Quirk et al. (1985) noted that the subjunctive were tends to be replaced by the indicative form was in the $1^{\text {st }}$ and $3^{\text {rd }}$ person singular of the past tense (e.g., If I were/was rich, I would buy you anything you wanted./Tim always speaks quietly on the phone, as though he were/was telling a secret.) (Note 2). In addition, Quirk et al. (1985) mentioned that this trend does not apply to the PUs if I were you and as it were. However, as examples (1) and (2) show, if I was you and as it was (Note 3) are observed in contemporary English (italicized by the author).

(1) a. The woman looked at her friend and back to Charlotte. "If I was you, I wouldn't be out walking in this weather unless I had somewhere I had to get to," the woman said.

(COCA, 2012) (Note 4)

b. I'd get out if I was you.

(Fowler 2004)

(2) a. MORGAN: Will Justin Bieber have that, do you think? Is it inevitable?

D. OSMOND: He's got it now. He's got it now. You know, that kind of success at that age can really bite you in the shorts, as it was, the proverbial shorts.

MORGAN: What would you say to him?

(COCA, 2011)

b. The journal had been intended as the perfect Austenesque birthday gift for my vintage-obsessed younger cousin. I'd found it lying alongside a worn copy of Pride and Prejudice in a quirky antiques shop down on South Congress and simply couldn't pass it up, hobnobbing, as it was, with greatness. (COCA, 2012)

Data collected from the Corpus of Contemporary American English (COCA) and the British National Corpus (BNC) (Note 5) report that the frequency of if I were you is much higher than that of if I was you, as shown in 
Table 1.

Table 1. Frequencies of if I were you and if I was you in the COCA and BNC

\begin{tabular}{lll}
\hline & if I were you & if I was you \\
\hline COCA & 378 & 59 \\
BNC & 152 & 37 \\
\hline
\end{tabular}

From Table 1, we can safely observe that the trend noted by Quirk et al. (1985) does not always hold in the case of the PU if I were you. To put it differently, was and were are interchangeably used, and the be verb is uniformed into was due to the working of merging when subjunctive mood is used.

Besides if I was you, the PU if it were not/weren't for can appear with the subjunctive was regardless of the register in which it is used, as seen in example (3).

(3) a. If it was not for family, friends, and a great law partner, I probably would be in the exact situation as Mr. Schultz. (COCA, written, 2006)

b. And if it was not for Title IX, I don't think I'd be in the position that I'm in today and be able to encourage other young girls who want to get into sports.

(COCA, spoken, 1997)

c. Nothing would get done if it wasn't for her.

(COCA, written, 2012)

Now we turn to as it was in (2). Previous research such as Jespersen (1954) argued that the shift from the subjunctive were to the subjunctive was cannot occur in as it were because the subjunctive was is difficult to distinguish from the was-indicative. However, as example (2) shows, as it was (with the subjunctive was) does indeed occur. As it was in (2a) is used to figuratively compare the shorts in "that kind of success at that age can really bite you in the shorts" with the ones. In (2b), as it was is used to emphasize the metaphor, which is the thing that the speaker found as a birthday gift lying alongside a worn copy of Pride and Prejudice is like going out with greatness.

This study descriptively shows that as it were is changing into as it was. It draws on data retrieved from corpora and how subjunctive as it was is used in context. Section 2 summarizes the previous research on as it were and as it was. Section 3 outlines the data used in the study. Section 4 presents a qualitative and quantitative analysis of as it were. The actual behavior of as it was is the main topic of Section 5. Based on the findings in Section 5, Section 6 presents elicitation from informants. Section 7 addresses related phenomena including such as it was. Section 8 summarizes the research.

\section{Previous Research on As It Were and As It Was}

Previous studies on as it were are too numerous to comprehensively list here. All of them regard subjunctive uses of as it was as mistakes and do not acknowledge its existence (e.g., Jespersen, 1954; Greenbaum \& Whitcut, 1988; Aarts, 2011; Quirk et al., 1985; Ishibashi (ed.), 1966; Watanabe (ed.), 1995; Yasui (ed.), 1993; Ando, 2005; Konishi (ed.), 2006). The $O E D^{2}$ defines as it were as "as if it were so," "if one might so put it," and "in some sort" and explains "a parenthetic phrase used to indicate that a word or statement is perhaps not formally exact though practically right." Like these studies, the $O E D^{2}$ does not acknowledge subjunctive as it was. Examples (4) and (5) are the definitions and examples of as it were quoted from dictionaries published in Europe and the U.S.

(4) a. used for making a description sound less definite or less exact

$\left(\mathrm{MED}^{2}\right)$

b. You say as it were in order to make what you are saying sound less definite [VAGUENESS] $\left(\mathrm{COB}^{8}\right)$

c. sometimes said after a FIGURATIVE (= not meaning exactly what it appears to mean) or unusual expression

$\left(\mathrm{CALD}^{4}\right)$

d. SPOKEN FORMAL used when describing someone or something in ways that are not completely exact

$\left(\mathrm{LAAD}^{2}\right)$

e. used when a speaker is giving his or her own impression of a situation or expressing sth in a particular way

$\left(\mathrm{OALD}^{8}\right)$

f. used when describing someone or something in ways that are not quite exact

$\left(\mathrm{LDCE}^{6}\right)$ 
(5) a. Mandela became, as it were, the father of the nation.

$\left(\mathrm{MED}^{2}\right)$

b. I'd understood the words, but I didn't, as it were, understand the question.

$\left(\mathrm{COB}^{8}\right)$

c. If he still refuses we could always apply a little pressure, as it were.

$\left(\mathrm{CALD}^{4}\right)$

d. He became famous, as it were, for never having a hit record.

$\left(\mathrm{LAAD}^{2}\right)$

e. Teachers must put the brakes on, as it were, when they notice students looking puzzled.

$\left(\mathrm{OALD}^{8}\right)$

f. Jim Radcliffe became our idol, as it were, the man we all wanted to be.

$\left(\mathrm{LDCE}^{6}\right)$

We can see from (4) and (5) that as it were mainly appears in the middle or at the end of sentences and is used to describe somebody or something figuratively without substantiating the description. On the other hand, English dictionaries published in Japan define as it were as used to rephrase an event A (somebody or something) as an event B and to compare an event A with an event B. There is discrepancy between dictionaries published in Europe and the U.S. and those of Japan concerning as it were. Hence, this study starts to re-examine the usage of as it were.

\section{Data and Research Method Used in the Study}

This study used data collected from the following existential corpora: The Corpus of Contemporary American English (http://corpus.byu.edu/coca/, COCA), the British National Corpus (http://bnc.jkn21.com/, BNC), and WordBanksOnline (http://wordbanks.jkn21.com/, WB). It is a basic requirement of research for a third party to verify the research results. Corpora make it possible for third parties to verify the research results at their convenience.

This study adopts the following simple and clear method to explain the actual behaviors of as it were and as it was: the meaning of a PU is closely related to the syntactic characteristics of the PU, which was explained in Inoue (2007) and has been widely used in linguistic studies.

\section{A Picture of As It Were in Actual Use}

Data derived from the BNC, WB, and COCA indicate that as it were appears in these databases 1005,523 , and 1733 times, respectively. These examples, however, include as it were followed by subsequent elements such as "For Ephrem, both Scripture and Creation are replete with God's symbols and mysteries, symbols which may point vertically, as it were to his trinitarian Being, or horizontally to his incarnate Son." (COCA, 2006). This study fully investigates, from semantic and syntactic perspectives, the 1000 examples of as it were observed in the COCA that do exclude such elements because as it were followed by subsequent elements is not an independently used PU. Table 2 summarizes the features of as it were.

As English dictionaries explain, as it were is used to indicate figurative expressions, but it can be subdivided into more detailed figurative usages, as Table 2 shows. As seen in Table 2, each usage has its own syntactic features, and as it were is used both as metaphor and as simile. In the BNC, as it were without subsequent elements has usages other than (2) in Table 2, but in WB it appears with all usages in Table 2. Examples of each usage in Table 2 are shown in (6) to (12).

Table 2. Usages and features of as it were

\begin{tabular}{|c|c|c|c|c|c|c|}
\hline & usage & $\begin{array}{l}\text { typically co-occurring } \\
\text { words or phrases }\end{array}$ & $\begin{array}{l}\text { position in a } \\
\text { sentence }\end{array}$ & $\%$ & metaphor or simile & ex. \\
\hline (1) & $\begin{array}{l}\text { analogy by using a word or a } \\
\text { phrase }\end{array}$ & like, noun (phrase) & middle or end & 13.6 & metaphor and simile & (6) \\
\hline (2) & paraphrasing an analogy & or & middle or end & 3.6 & metaphor & (7) \\
\hline (3) & analogy of a subject & be verb, copular verb & $\begin{array}{l}\text { middle (after be } \\
\text { verb and copular } \\
\text { verb) }\end{array}$ & 6.9 & metaphor & $(8)$ \\
\hline (4) & unconfirmed analogy & $\begin{array}{l}\text { sort of, kind of, if-clause, } \\
\text { subjunctive }\end{array}$ & middle or end & 6.2 & metaphor and simile & (9) \\
\hline (5) & $\begin{array}{l}\text { analogy done by a previously } \\
\text { mentioned context }\end{array}$ & & middle or end & 26.7 & metaphor & $(10)$ \\
\hline (6) & $\begin{array}{l}\text { analogy to emphasize what is } \\
\text { going to be said }\end{array}$ & & $\begin{array}{l}\text { middle, before or } \\
\text { after an preposition }\end{array}$ & 42.9 & metaphor & (11) \\
\hline (7) & used to say something difficult & & middle & 0.1 & & $(12)$ \\
\hline
\end{tabular}


(6) a. The text can't just exist in English because the hybridity of the tongue is important on the border. Spanglish and Espangls, can only exist when engendered by the two mother tongues and so the play has two settings - two stations as it were: there is the Real World, where characters speak whatever they speak, and then there's the Translated World, where light and sound sort of turn the dial up on the English.

(COCA, 2011)

b. Since you are a wizard of sorts, you are of course aware that we live upon a world shaped, as it were, like a disc?

(BNC, 1983)

As it were in (6) shows comparison by using concrete nouns (or noun phrases). In that case, the word like appears near as it were. As it were appears in the middle or at the end of a sentence and has metaphoric and simile functions. In (6a), as it were is used to show a concrete comparison (i.e., two stations) by saying as if the text had two stations. In the case of (6b), as it were introduces the simile equating the world's shape with a disc.

(7) a. KAYE: That is such a great story. The question is, though, did the phone ever ring for C.J.?

GRIFFIN: Once. The New York Mets called him down to Florida, had him try out, and they never called back. But he got a different call. This is a different - a role (sic. roll) call, as it were. (COCA, 2012)

b. Mr-ZAKHEIM:.... You simply don't have the same kind of, what the military calls, situational awareness, what normal human beings as it were or people speaking English would call knowing what's going on.

(COCA, 2010)

As it were in (7) is used to paraphrase something. In this case, as it were tends to co-occur with or and has only a metaphoric function. In (7a), as it were paraphrases a different call as a roll call. Moreover, call is has two meanings "dial" and "summons", which is referred to as a pun. As it were in (7b) is used to put normal human beings into people speaking English.

(8) a. As Bowlby argues, while a child lacks the "rudiments of conscience," the mother diverts the child from socially negative actions, even while allowing him some freedom; acting on the child's behalf, as Bowlby phrases it, "She is, as it were, his personality and his conscience." $\quad$ (COCA, 2012)

b. Is this just a temporary - temporary hiccup? Is it a, as it were, a routine rather savage adjustment to the Japanese economy or are we seeing the unraveling of the Japanese economy? (WB, 1992)

As it were in (8) paraphrases the state or feature of a subject into something different using concrete words or phrases. The usage is only used as a metaphor. In (8a), the subject she is equated with his personality and his conscience by as it were. As example (8) shows, as it were used in the usage is always located after copular verbs.

(9) a. What they can't handle now are the fuel costs. And the fuel costs have sort of offset all the benefits they've gotten from their cost reductions. So that if it weren't for the fuel prices, if fuel were priced as it were, say, a year ago, they would have made money collectively during the second quarter; as it is, a couple did anyway.

(COCA, 2005)

b. While this might appear to "balance the books," as it were, and to make for equal exchange, what George Steiner innocently terms "exchange without loss," in fact it reaps dividends for the West's own humanism, as Derrida argues, and as Lienhardt and Malinowski prove. (WB, 1993)

In (9), as it were introduces an unconfirmed or counterfactual comparison in the subjunctive mood or in an if-clause. In this case, as it were tends to co-occur with sort of or kind of. The usage is used both as metaphor and as simile.

(10) a. BAIER: Tonight, we bring you the second addition (sic. edition) of our special visits with the Republican presidential candidates. This evening we welcome our guest, former New Mexico Governor Gary Johnson. Governor, thanks for being here.

GARY-JOHNSON-1R: Great being on here, Bret.

BAIER: Sure. Jonah, let's start with you.

GOLDBERG: I drew the short straw, as it were.

(COCA, 2011)

b. Mr-PRYCE: Well, I'm Welsh, so my basic accent is-well, it was before I went to drama school — was a Welsh accent. And I've learned how to speak English, as it were.

(COCA, 2001) 
As it were in (10) is used to compare a feeling or an event caused by previously mentioned events or states with something else. This usage only works metaphorically and appears in the middle or at the end of a sentence. In the case of (10a), Goldberg compares the first question thrown into "I drew the short straw" by saying as it were. In (10b), Pryce uses as it were to qualify his statement "I've learned how to speak English," since his native tongue was actually English.

(11) a. "I looked at him quizzically." "Night and Fog," Danforth translated. "The German policy of sending prisoners to camps where they would disappear into, as it were, night and fog."

(COCA, 2011)

b. He didn't understand the implications of his actions, but he soon would. He'd later explain that something was tugging at his spirit, begging him, as it were, to stay.

(COCA, 2011)

c. Well, thank you very much indeed, er, the resolution is er, carried. Erm, we're coming as it were to the end of the first part of the proceedings, er, but, I'd like to give a brief thanks to the er, C R group, that's the Charities Recruitment Group, for the part sponsorship of this A G M Conference.

(BNC, 1991)

d. He used laser beams actually to, as it were, lift an experimental train onto a track inside a cell.

(WB, 1990)

e. Intelligent design is really a stand-alone science. It's looking for the engineering features, as it were, of biological systems.

(COCA, 2005)

f. His miracles of building this new perspective, conformed to the biblical miracles in both Testaments, are truly the work of God. Yet Benedict becomes so addicted, as it were, to these displays of power that he grows deaf to the simplest request of charity, ....

(COCA, 2007)

g. The religionists of our time are occupying about the same ground occupied by heretics and infidels of one hundred years ago. The church has advanced in spite, as it were, of itself.

(COCA, 1999)

h. This would, I think, lead to a quite implausible account of ordinary knowledge of your own thoughts on which you had, as it were, a "double awareness" of their contents,....

(COCA, 1999)

i. "What about the storage space business? Where did that come from?" "I figured I hadda (sic. had to) do something when the roofing trade fell in. "As it were," he added with a wink at me. "I decided to try salvage. I had some cash tucked away the wife and the creditors didn't know about so I used that to get started...."

(COCA, 2001)

This usage, to emphasize comparison, is the most common usage of as it were. As (11) shows, the typical syntactic feature of this usage is that as it were is typically positioned before and after a preposition, working like a parenthetical expression, in order to emphasize the contents located around the preposition and to lend suspense to what a speaker is about to say. For example, in (11b), as it were is used to emphasize "to stay" in "begging him to stay" as among the possible objects of begging. In (11g), as it were is interestingly inserted inside the PU in spite of and serves to emphasize itself. As it were in (11h) is used emphasize "double awareness." In (11i), as it were is independently used to emphasize "I decided to try salvage" if "when the roofing trade fell in" becomes true.

(12) ... "I may, provided you don't feel that I'd be, as it were, trespassing in your territory, sir, be able to be of some assistance."

(COCA, 2012)

The usage of as it were in (12) is observed in only one example. As it were is used to broach an awkward subject ("trespassing in your territory") or used as a hedge.

Thus, as it were can be classified into two main types in the data, as is shown in (13). As English dictionaries explain, as it were is used to describe something figuratively without commitment to its truth.

(13) as it were (figuratively used)

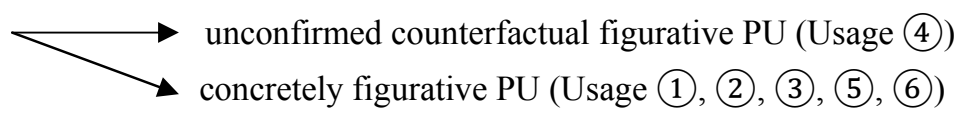

Considering the $O E D{ }^{\prime 2} \mathrm{~s}^{2}$ definition, the two usages of as it were began as PUs with unconfirmed counterfactual figurative readings, and then developed into usage as a concretely figurative PU. 


\section{As It Was}

\subsection{Its Usage}

As it was appears 6534 times in the COCA, but most of these are indicative expressions such as "as odd as it was," or "as it was impossible ...," which are not the topic of the study. A close investigation of the 2000 examples of as it was used independently show that about $85 \%$ of the instances of as it was are indicative, such as the following example:

(14) No one would ever be friends with her if they remained in that town. As it was, no one wanted to be her friend later, either, once they found out who she was.

(COCA, written, 2011)

Indicative was tends to be used at the beginning of a sentence after subjunctive past or subjunctive past perfect sentences. Indicative as it was is used to contrast counterfactual contents from those mentioned in the subjunctive past or subjunctive past perfect. Indicative as it was is not the subject of this study, but $15 \%$ of subjunctive as it was is descriptively classified in the study. Corpora data show that subjunctive as it was has the same usages (1), (2), (4), and (6)) as as it were in Table 2. Each usage of as it was is shown in (15), (16), (17), and (18).

(15) MORGAN: Will Justin Bieber have that, do you think? Is it inevitable?

D. OSMOND: He's got it now. He's got it now. You know, that kind of success at that age can really bite you in the shorts, as it was, the proverbial shorts.

MORGAN: What would you say to him?

(COCA, spoken, 2011)

(16) It was Ramadan, they would go home for dinner. Go home and have, you know, descend from the mountains and come back and fight another day. It was not a professional fighting force, even if it was, you know, not taking bribes or not sort of also internally in conflict, as it was.

(COCA, spoken, 2011)

(17) We'd learned our trades from our uncles, who never felt like fathers, but who taught us how to be men. Without ever saying as much, my uncle taught me that any of us could become my father, and if we faulted him, we'd have less grace for ourselves. And that grace would be hard to find in this life, as it was.

(COCA, written, 2012)

(18) "It's her body," Helen had said to Nathan, in defense of the Germany plan. The word "body" sank to the ground the minute she said it, weighted, as it was, with the idea of his body and his desires, which had managed so casually to reject hers.

(COCA, written, 2006)

As it was in (15), (16), (17), and (18) is used as a metaphor and has the same features of each usage of as it were given in Table 2. As it was in (15) is repeated from (2a), and concretely compares "the shorts" in "that kind of success at that age can really bite you in the shorts" with "the proverbial shorts." In the case of (16), as it was is used to metaphorically paraphrase it as something different (taking bribes and sowing internal conflict). In (17), as it was metaphorically highlights the speaker's unconfirmed opinion (that grace would be hard to find in this life). As it was in (18) is used to metaphorically emphasize "weighted with the idea of his body and his desires, which had managed so casually to reject hers" when she said the word "body."

As it was followed by subsequent elements is found in 1997 examples in the BNC and in 1554 examples in the WB, but only one example of as it was without subsequent elements in each corpus used in this study is observed as example (19) shows.

(19) a. He had got bored with cars and the business with Lucky Lady Firelight seemed more challenging. The prospect of Sam's motorbike, mouth-watering as it was, was too far off coming true to be worth thinking about yet, if ever.

(BNC, written, 1988)

b. ..., the town never could have sheltered the surrounding farmers, with all their families and livestock, for these last weeks of waiting. Things would soon be bad enough inside the walls as it was.

(WB, written, 1993)

In (19a), as it was reflects usage (1) in Table 2 and explains the prospect of Sam's motorbike being very attractive as if the speaker would kill for it. As it was in (19b) reflects usage (4) in Table 2 and is used to compare the situations caused by what previously happened into "things would soon be bad enough inside the walls." As it was in (19) thus works as metaphor.

As it was (the subjunctive was) has the same figurative functions as as it were, but it does not always have all the 
usages of as it were as shown in (20). This is due to the merging of was and were, as seen in if I were you and if I was you, if it were not/weren't for and if it was not/wasn't for. Tokens of subjunctive as it was, the topic of this study, are few and far between in contemporary English; however, as it was has come to be increasingly used as a variant of as it were with the same usages.

(20) as it was (figuratively used)

a. (i) analogy by using a word or a phrase

(ii) paraphrasing an analogy concretely figurative PU

(iii) analogy to emphasize what is going to be said

b. unconfirmed counterfactual analogy - unconfirmed counterfactual figurative PU

Schibsbye (1970) mentioned that the subjunctive was has a greater degree of certainty than the subjunctive were, but this does not hold true of subjunctive as it was.

Why does this semantic distinction not occur when the subjunctive were is replaced by the subjunctive was in PUs such as if I were you, if it were not/weren't for, and as it were? Each PU has its own meaning (i.e., semantic fixity) when the subjunctive were is used. If some syntactic change happens within a PU, its semantic fixity is not stable. This means that the PU is not a PU but merely a free combination. Consequently, as far as I have investigated from the limited data for subjunctive as it was collected from corpora, there is no semantic difference between as it were and as it was.

\subsection{Register and American English vs British English}

$89 \%$ (132 examples) of all examples of subjunctive as it was (148 examples) in the COCA appear in written texts, and the remaining $11 \%$ (16 examples) appear in spoken texts. This leads us to believe that subjunctive as it was has becomes a widespread PU.

As (19) shows, only two examples of subjunctive as it was are observed in British English. It is safe to mention that the transition from the subjunctive were to the subjunctive was is a linguistic feature of American English.

\section{Informants' Elicitations}

I asked four native speakers of English (one American, British, Canadian, and Australian speaker) to answer the questionnaire in (21) to confirm the results and discussion of this study. Because the answers that each informant chose were either as it were or as it was, no regional differences emerged (Table 3). The right answer for each question is highlighted in Table 3 .

(21) Could you fill in the blank by choosing either as it were or as it was?

(1) Since you are a wizard of sorts, you are of course aware that we live upon a world shaped, ( ), like a disc?

(2) KAYE: That is such a great story. The question is, though, did the phone ever ring for C.J.?

GRIFFIN: Once. The New York Mets called him down to Florida, had him try out, and they never called back. But he got a different call. This is a different -a role (sic. roll) call, (

(3) Is this just a temporary-temporary hiccup? Is it a, ( ). adjustment to the Japanese economy or are we seeing the unraveling of the Japanese economy?

(4) What they can't handle now are the fuel costs. And the fuel costs have sort of offset all the benefits they've gotten from their cost reductions. So that if it weren't for the fuel prices, if fuel were priced ( ), say, a year ago, they would have made money collectively during the second quarter; as it is, a couple did anyway.

(5) BAIER: Tonight, we bring you the second addition (sic. edition) of our special visits with the Republican presidential candidates. This evening we welcome our guest, former New Mexico Governor Gary Johnson. Governor, thanks for being here.

GARY-JOHNSON-1R: Great being on here, Bret.

BAIER: Sure. Jonah, let's start with you.

GOLDBERG: I drew the short straw, ( ).

6 "I looked at him quizzically." “"Night and Fog,", Danforth translated. "The German policy of sending prisoners to camps where they would disappear into, ( ), night and fog." 
(7) Intelligent design is really a stand-alone science. It's looking for the engineering features, ( ), of biological systems.

(8) This would, I think, lead to a quite implausible account of ordinary knowledge of your own thoughts on which you had, ( ), a "double awareness" of their contents,....

(9) "What about the storage space business? Where did that come from?" "I figured I hadda (sic. had to) do something when the roofing trade fell in. '( )," he added with a wink at me. "I decided to try salvage. I had some cash tucked away the wife and the creditors didn't know about so I used that to get started...."

(10) ... "I may, provided you don't feel that I'd be, ( $)$, trespassing in your territory, sir, be able to be of some assistance."

(11) MORGAN: Will Justin Bieber have that, do you think? Is it inevitable?

D. OSMOND: He's got it now. He's got it now. You know, that kind of success at that age can really bite you in the shorts, ( ), the proverbial shorts.

MORGAN: What would you say to him?

(12) The journal had been intended as the perfect Austenesque birthday gift for my vintage-obsessed younger cousin. I'd found it lying alongside a worn copy of Pride and Prejudice in a quirky antiques shop down on South Congress and simply couldn't pass it up, hobnobbing, ( ), with greatness.

(13) It was Ramadan, they would go home for dinner. Go home and have, you know, descend from the mountains and come back and fight another day. It was not a professional fighting force, even if it was, you know, not taking bribes or not sort of also internally in conflict, ( ) .

(14) We'd learned our trades from our uncles, who never felt like fathers, but who taught us how to be men. Without ever saying as much, my uncle taught me that any of us could become my father, and if we faulted him, we'd have less grace for ourselves. And that grace would be hard to find in this life, ( $)$.

(15) "It's her body," Helen had said to Nathan, in defense of the Germany plan. The word "body" sank to the ground the minute she said it, weighted, (

), with the idea of his body and his desires, which had managed so casually to reject hers.

Table 3. Results of (21)

\begin{tabular}{|c|c|c|}
\hline & as it were & as it was \\
\hline (1) & 4 & \\
\hline (2) & 4 & \\
\hline (3) & 1 & 3 \\
\hline (4) & 1 & 3 \\
\hline (5) & 4 & \\
\hline (6) & 4 & \\
\hline (7) & 4 & \\
\hline (8) & 4 & \\
\hline (9) & 4 & \\
\hline (10) & 4 & \\
\hline (11) & 3 & 1 \\
\hline (12) & 3 & 1 \\
\hline (13) & 3 & 1 \\
\hline (14) & 3 & 1 \\
\hline (15) & 3 & 1 \\
\hline
\end{tabular}

In (3), the three informants chose as it was since they must have thought the question asked what actually happened. In (4), three informants selected as it was in a subjunctive mood sentence, which means they interpreted as it was as subjunctive. Only one informant chose as it was in (11) to (15) when the sentences expressed metaphors. These findings suggest that native speakers of English have a slight tendency to use as it was when a sentence has a figurative sense, but as it was is an unfamiliar PU. 


\section{Such As It Was}

Such as it was is observed 130 times in the COCA only. Unlike the meaning and the syntactic patterns of subjunctive as it was, such as it was is used to mean "actually" or "in practice" and has three syntactic patterns: (1) located after a noun (phrase), (2) at the end of a sentence, and (3) located before a preposition. Clear examples of each syntactic pattern are shown in (22).

(22) a. And to add insult to injury, Stan Wykoff's reputation, such as it was, was enhanced by his being the agent of best-selling author Jack Henry.

(COCA, written, 2011)

b. "Pass 'em," Pounds ordered. "I'll wait for them in the lobby." Jessica Kincaid leaned close to whisper, "What did he say?" "Tell you later." Janson sat back and watched the scenery, such as it was. Outside the taxi window Houston looked hot and dry, a flat, new land empty of people and full of cars.

(COCA, written, 2011)

c. I lay in bed surrounded by briefs and documents and books that looked like detritus the tide brought in. I worked, such as it was, until about eleven o'clock and then I took a pill.

(COCA, written, 2010)

In (22a), where such as it was appears after a noun phrase, it is used to emphasize the content of the noun phrase (was enhanced by his being the agent of best-selling author Jack Henry). In (22b), such as it was is used to emphasize what previously happened or a previous event (i.e., sat back and watched the scenery). Here, such as it was is located before a preposition in (22c), and the content following the preposition (until about eleven o'clock) is emphasized.

From my investigations of the COHA data, such as it was first appeared in 1823, so is not a newly observed PU.

\section{Conclusion}

The widely known rule that the subjunctive were can be replaced with the subjunctive was observed in contemporary English is applicable to the PU as it were, despite previous research not recognizing as it was as a legitimate equivalent and considering any tokens of it as errors. Furthermore, this study clarifies the actual behavior of as it was in different contexts. Consequently, the merger of the subjunctive were and the subjunctive was is not an anomalous phenomenon in PUs.

\section{References}

Aarts, B. (2011). Oxford Modern English Grammar. Oxford: Oxford University Press.

Ando, S. (2005). Gendai Eibunpou Kougi. (Lectures on Modern English Grammar.) Tokyo: Kaitakusha.

Fowler, H. W. (2004). Fowler's Modern English Usage (3rd ed.). Oxford: Oxford University Press.

Greenbaum, S., \& Whitcut, J. (1988). Longman guide to English usage. London: Longman.

Inoue, A. (2007). Present-day Spoken English: A Phraseological Approach. Tokyo: Kaitakusha.

Inoue, A. (2014). Actual Behaviors of Newly Observed Phraseological Units Comprising Two Prepositions. International Journal of English Linguistics, 4(4), 74-87. http://dx.doi.org/10.5539/ijel.v4n4p74

Inoue, A. (2015). Newly observed phraseological units with noun forms of modal verbs. Lexicography: Journal of ASIALEX, 1(2), 137-157. http://dx.doi.org/10.1007/s40607-014-0011-2

Ishibashi, K. (Ed.). (1966). Eigo Gohou Daijiten (A Dictionary of Current English Usage I). Tokyo: Taishukanshoten.

Jespersen, O. (1954). A modern English grammar on historical principles - Part IV - Syntax. London: Allen \& Unwin.

Konishi, T. (Ed.). (2006). Gendai Eigo Gohou Jiten (Sanseido's Dictionary of Present-day English Usage). Tokyo: Sanseido.

Quirk, R., Greenbaum, S., Reech, G., \& Svartvik, J. (1985). A comprehensive grammar of the English language. London: Longman.

Schibsbye, K. (1970). A modern English grammar. Oxford: Oxford University Press.

Sinclair, J. M. (Ed.). (1992). Collins COBUILD English usage for learners. London: Harper Collins.

Watanabe, T. (Ed.). (1995). Eigo Gohou Daijiten, Vol. 4. (A Dictionary of Current English Usage IV). Tokyo: Taishukanshoten. 
Yagi, K. (1999). Eigo no Bunpou to Gohou - Imikara no Approach (A Semantic Descriptive Approach to Modern English). Tokyo: Kenkyusha Syuppan.

Yasui, M. (Ed.). (1993). Kaiteiban Eibunpou Souran (A Better Guide to English Grammar). Tokyo: Kaitakusha.

\section{Notes}

Note 1. This study defines phraseological units as frequently used combinations consisting of at least two words. Also, the study adopts the most widespread term, "phraseological units" (PUs), although various terms such as "phraseme" and "recurrent word-combinations" are also used.

Note 2. Schibsbye (1970) explained that the degree of uncertainty greatly influences the choice of either is, was or were and changes depending on is/was/were. For example, let us consider the sentence "If it is/was/were true, I should know it." When indicative "is" is used (e.g., if it is true), it implies that it is obvious that it is true. On the other hand, if "if it was true" implies a degree of doubt, then "if it were true" shows that it is not true at all.

Note 3. As it was, which is the focal phraseological unit of this study, of course excludes as it was as the was-indicative (e.g., I left it as it was).

Note 4. COCA is the abbreviation of Corpus of Contemporary American English. I accessed it on November 30th and December 1st, 2014.

Note 5. I accessed BNC on November 30th and December 1st, 2014.

\section{Corpora}

British National Corpus (BNC)

Corpus of Contemporary American English. (COCA) Available at http://corpus.byu.edu/coca/.

Corpus of Historical American English (COHA) Available at http://corpus.byu.edu/coha/.

WordBanksOnline (WB)

\section{Dictionaries}

$C A L D^{4}$ : Cambridge Advanced Learner's Dictionary. 4th edition. 2013. Cambridge: Cambridge University Press.

COB $^{8}$ : Collins COBUILD Advanced Learner's Dictionary. 8th edition. 2014. Glasgow: HarperCollins Publishers.

$L A A D^{2}$ : Longman Advanced American Dictionary. $2^{\text {nd }}$ edition. 2007. London: Longman.

$L D C E^{6}:$ Longman Dictionary of Contemporary English. $6^{\text {th }}$ edition. 2014. London: Longman.

$M E D^{2}$ : Macmillan English Dictionary. $2^{\text {nd }}$ edition. 2007. Oxford: Macmillan Education.

OALD ${ }^{8}:$ Oxford Advanced Learner's Dictionary. $8^{\text {th }}$ edition. 2011. Oxford: Oxford University Press.

OED ${ }^{2}$ : Oxford English Dictionary on Historical Principle. $2^{\text {nd }}$ edition on CD-ROM Version 4. 2009. Oxford: Oxford University Press.

Webster's Dictionary of English Usage. 1989. Massachusetts: Merriam-Webster.

\section{Copyrights}

Copyright for this article is retained by the author(s), with first publication rights granted to the journal.

This is an open-access article distributed under the terms and conditions of the Creative Commons Attribution license (http://creativecommons.org/licenses/by/3.0/). 